\section{Akgüney İskelet Toplumu Dişlerinin Paleopatolojik Açıdan İncelenmesi}

\author{
Ayşegül ŞARBAK ${ }^{1 *} \odot$ \\ 1 Dr. Öğr. Üyesi. Hitit Üniversitesi, Fen - Edebiyat Fakültesi, Antropoloji Bölümü, \\ Çorum / TÜRKIYE
} \begin{abstract}
E-posta: aysegulsarbak@hitit.edu.tr
Alındı/Received: 3 Nisan / April 2019
Düzeltildi/Revised: 10 Eylül / September 2019
Kabul/Accepted: 23 Eylül / September 2019
Erken Görünüm / Early View: 25 Ekim / October 2019
Yayımlandı/Published: 20 Aralık / December 2019 Alındı/Received: 3 Nisan / April 2019
Düzeltildi/Revised: 10 Eylül / September 2019
Kabul/Accepted: 23 Eylül / September 2019
Erken Görünüm / Early View: 25 Ekim / October 2019
Yayımlandı/Published: 20 Aralık / December 2019 Alındı/Received: 3 Nisan / April 2019
Düzeltildi/Revised: 10 Eylül / September 2019
Kabul/Accepted: 23 Eylül / September 2019
Erken Görünüm / Early View: 25 Ekim / October 2019
Yayımlandı/Published: 20 Aralık / December 2019 Alındı/Received: 3 Nisan / April 2019
Düzeltildi/Revised: 10 Eylül / September 2019
Kabul/Accepted: 23 Eylül / September 2019
Erken Görünüm / Early View: 25 Ekim / October 2019
Yayımlandı/Published: 20 Aralık / December 2019 Alındı/Received: 3 Nisan / April 2019
Düzeltildi/Revised: 10 Eylül / September 2019
Kabul/Accepted: 23 Eylül / September 2019
Erken Görünüm / Early View: 25 Ekim / October 2019
Yayımlandı/Published: 20 Aralık / December 2019
\end{abstract}

Hitit Üniversitesi, Fen - Edebiyat Fakültesi Kampüsü, Antropoloji Bölümü, Çorum / TÜRKIYE Antropoloji Bölümü, Çorum / TURKIYE
E-posta: aysegulsarbak@hitit.edu.tr Paleopathological Investigation of the Teeth of Akgüney Skeleton Population

\begin{abstract}
The Akgüney population, dated to the Late Roman-Early Byzantine period, is located in the province of Sinop. The aim of the study is to determine the bealth structure of the population by examining the teeth of Akgüney population in terms of paleopathological aspects. Teeth are the most important materials representing the nutritional state and health status of ancient population. For this reason, 631 teeth belonging to 170 individuals of the Akgüney community were investigated from a paleopathological point of view. As a result of the analyses, 9,12\% tooth decay, $28,98 \%$ dental calculus and 40,21\% bypoplasia were seen in the population. In addition, $7.82 \%$ of the antemortem tooth loss, $41.43 \%$ of alveolar bone loss, and $1.16 \%$ of abscesses were detected in the population. According to the rate of wear in the population, middle (3) degree tooth wear was observed the most in population. The tooth caries, teeth calculus and bypoplasia ratios of Akgüney populations are close to the contemporary population. The abscess, one of the pathological conditions that reflect dental health and oral bygiene, is a little lower than of contemporary populations. It is seen that the degree of tooth wear is close to that of contemporary populations. As a result, findings show that carbohydrate nutrients are found in the diet of Akgüney populations, whereas tooth decay, antemortem tooth loss and alveolar bone loss rates indicate that the oral bygiene and dental bealth of the population are not very good.
\end{abstract}

Key Words: Teeth health, dental pathology, Byzantium

konulmasını sağlamaktadır. Diş patolojilerinin birbirlerinden bağımsız olarak gelişmediklerini ve aralarında ilişki olduğunu unutmamak gerekir (Roberts ve Manchester, 2012). Dişlerde oluşan diş taşı, diş̧ etlerini tahriş ederek enfeksiyon oluşmasına, alveol kemik kaybına ve en sonunda dişin kaybedilmesine neden olabilir. Benzer şekilde çok sert besinlerle beslenen bireylerin dişlerinin çok fazla aşınması dişleri zayıflatır ve bakteriler pulpa boşluğuna inerek dişte apsenin oluşmasına neden olur. Toplumlarda diş patolojilerinin görülme sıklıkları yaş ve cinsiyete bağlı olarak değişebilmektedir. Antemortem diş kaybının ve alveol kemik kaybının yaşla doğru orantılı olduğu çeşitli araşıtırmacılar tarafindan kanıtlanmıştır (Mays, 
1998; Çırak vd., 2009; Y1lmaz Usta, 2013; Göksal, 2017). Çürük oluşumun ise kadın bireylerde erkek bireylere oranla daha fazla görüldügü birçok araştırmada gösterilmiştir (Larsen vd., 1991; Vanna, 2007; Roberts ve Manchester, 2012). Diş patolojileriyle beslenme yapisı arasında sıkı bir ilişki olduğu bilinmektedir. Çok sert ve taneli besinlerle beslenen bireylerin dişlerinde aşınma gözlenirken, diş taşı oluşumu daha az görülmektedir (Özbek, 2015). Geçimini büyük çoğunlukla tarımla sağlayan toplumlarda ise diş çürügü ve diş taşı görülme oranı daha yüksek iken, beslenmesinin büyük kısmını hayvansal proteinlerin oluşturduğu toplumlarda diş taş1 ve çürük oranı daha azdır (Mays, 1998).

Çalışmanın amac1, Akgüney Toplumunun dişlerini paleopatolojik açıdan inceleyerek toplumun diş sağllğı hakkında bilgi edinmektir. Bu doğrultuda, Akgüney kazılarından çıkarılan 170 bireye ait 631 diş, diş çürügüu, aşınma, diş taşı, hipoplasya, apse, alveol kemik kaybı ve antemortem diş kaybı açısından incelenmiştir. Elde edilen verilerin cinsiyet, yaş ve diş grupları arasındaki dağılımları incelenmiş ve istatistik açıdan değerlendirilmiştir. Ayrıca çağdaşı olan diğer Eski Anadolu toplumlarıyla karşılaştırllarak Akgüney Toplumu'nun yeri ve önemi belirtilmiştir.

\section{Gereç ve Yöntem}

Geç Roma-Erken Bizans Dönemin tarihlendirilen Akgüney Toplumu Sinop İli Gerze ilçesine bağlı Akgüney Köyü’nde yer almaktadır. Akgüney Köyü, Değirmen yanı Mevkiinde; Cengiz İnşaat San. ve Ticaret A.Ş. taahhüdü altında yapımı devam eden Güzelce ÇayDikmen karayolu yapım inşaatı sırasında tespit edilen Akgüney toplumu kazısı 2013 y1lında Sinop Müzesi tarafindan gerçekleştirilmiştir (Harita 1). Çalışma sahası, 60 metre eninde ve 100 metre uzunluğundaki bir alanı kapsamaktadır. Kazı çalışması sırasında bu alanda 4 adet yap1 kalıntısı, 1 adet 2 odalı mezar yapısı ile 83 adet mezar tespit edilmiştir.

Akgüney Toplumunda toplam 170 birey ele geçirilmiştir. Akgüney toplumunun Paleodemografik değerlendirmesi Çırak (2017) tarafindan yapılmıştır. Bu çalışmaya göre 170 bireyin \%26,5'i erkek birey, \%25,2'si kadın birey, \%6,5 adölesan, \%9,4'ü çocuk, \%10,6’s1 bebek olarak belirlenmiştir. \%21,8'nin ise cinsiyeti tespit edilememiştir (Tablo 1).

Toplumun yaş dağılımına bakıldığında ise; \%8,8'nin genç erişkin, \%8,2'sinin orta erişkin, \%7,1'nin ileri erişkin olduğu görülmektedir. Yaş1 tespit edilemeyen erişkin bireylerin oranı ise \% 49,4 olarak bulunmuştur (Çırak, 2017). Bireylerin yaş gruplandırmaları White ve arkadaşlarının (2012) belirlediği yaş aralıklarına göre yapilmıştır (Tablo 2).

Akgüney toplumunda 170 bireye ait 631 diş paleopatolojik açıdan incelenmiştir. Dişlerin dağılımına bakıldığında 243'ü kadın, 130'u erkek, 22'si adölesan, 43'ü çocuk, 50'si ise bebeklere ait olduğu tespit edilmiştir. Diş dağılımlarına diş grupları açısından bakıldığında en çok 2. moların (n: 106) olduğu görülürken, ikinci sırada ise 1. molar (n: 105) yer almaktadır (Tablo 3).

Tablo 1. Akgüney toplumunda cinsiyet dağılımı (Çırak, 2017).

\begin{tabular}{ccc}
\hline Grup & $\mathbf{n}$ & $\mathbf{\%}$ \\
\hline Erkek & 45 & 26,5 \\
Kadın & 43 & 25,2 \\
Adölesan & 11 & 6,5 \\
Çocuk & 16 & 9,4 \\
Bebek & 18 & 10,6 \\
Belirsiz & 37 & 21,8 \\
Toplam & $\mathbf{1 7 0}$ & $\mathbf{1 0 0}$ \\
\hline
\end{tabular}

Tablo 2. Akgüney toplumunda yaş dağılımı (Çırak, 2017).

\begin{tabular}{ccc}
\hline Yaş* & $\mathbf{n}$ & $\mathbf{\%}$ \\
\hline Bebek & 18 & 10,6 \\
Çocuk & 16 & 9,4 \\
Adölesan & 11 & 6,5 \\
Genç erişkin & 15 & 8,8 \\
Orta erişkin & 14 & 8,2 \\
İleri erişkin & 12 & 7,1 \\
Erişkin & 84 & 49,4 \\
TOPLAM & $\mathbf{1 7 0}$ & $\mathbf{1 0 0}$ \\
\hline
\end{tabular}

* Yaş grupları: Bebek (0-3 yaş), Çocuk (3-12 yaş), Adölesan (12-20 yaş), Genç Erişkin (20-35 yaş), Orta Erişkin (35-50 yaş), İleri Erişkin (50+ yaş) olarak ele alınmıştır (White vd., 2012).

\section{Paleopatolojik Yöntemler}

Akgüney Toplumunun dişlerinde bulunan patolojiler bilim insanlarının belirlemiş oldukları yöntemlere göre incelenmiştir. Buna göre diş çürükleri Buikstra ve Ubelaker,1994; Caselitz,1998 geliştirmiş olduğu yöntemler dikkate alınarak incelenmiştir. Buna göre çürükler; 1: Oklusyal Yüzey; 2: İnterproksimal Yüzey; 3: Düz Yüzey (Bukkal ve lingual yüzey); 4: Cervical Çürükler (CEJ); 5: Kök Çürükleri; 6: Geniş Çürükler; 7: Diş tacinın tamamen yok olduğu pulpaya inen çürükler olarak sınıflandırılmıştır. Diş taşı birikimleri ise, Brothwell (1981)'in geliştirdiği yönteme göre incelenmiştir. Buna göre, 0: Diş taş1 yok, 1: Az, 2: Orta, 3: İleri olarak ele alınmıştır. Toplumdaki hipoplasya oranı Schultz ve diğ. (1998)'in kullandiğı yönteme göre belirlenmiştir. Buna göre; 0: Hipoplasya yok; 1: Mine tabakasinda mat beyaz veya kremsi renklenme; 2: Mine tabakasında sarı veya kahverengi renklenme; 3: Mine 
Şarbak | Antropoloji 38 (2019), 5-19

Tablo 3. Akgüney toplumunun diş dağılımı

\begin{tabular}{cccccccc}
\hline DİŞ & Kadın & Erkek & Adölesan & İzole & Çocuk & Bebek & TOPLAM \\
\hline I1 & 18 & 7 & 4 & 13 & 0 & 9 & $\mathbf{5 1}$ \\
I2 & 26 & 11 & 2 & 15 & 6 & 6 & $\mathbf{6 6}$ \\
C & 37 & 17 & 4 & 18 & 7 & 13 & $\mathbf{9 6}$ \\
P1 & 38 & 18 & 3 & 21 & 0 & 0 & $\mathbf{8 0}$ \\
P2 & 31 & 21 & 3 & 12 & 2 & 0 & $\mathbf{6 9}$ \\
M1 & 33 & 24 & 3 & 20 & 15 & 10 & $\mathbf{1 0 5}$ \\
M2 & 34 & 19 & 3 & 25 & 13 & 12 & $\mathbf{1 0 6}$ \\
M3 & 26 & 13 & 0 & 19 & 0 & 0 & $\mathbf{5 8}$ \\
TOPLAM & $\mathbf{2 4 3}$ & $\mathbf{1 3 0}$ & $\mathbf{2 2}$ & $\mathbf{1 4 3}$ & $\mathbf{4 3}$ & $\mathbf{5 0}$ & $\mathbf{6 3 1}$ \\
\hline
\end{tabular}

tabakasinda küçük oluklar; 4: Mine tabakasinda yatay oluklar; 5: Mine tabakasında dikey oluklar; 6: Dişte mine tabakası oluşmamış olarak kaydedilmiştir. Diş aşınmaları Brothwell (1981) ve Ubelaker (1978)'in geliştirmiş olduğu yöntemlere göre incelenmiştir. Antemortem diş kayıpları belirlenirken yok: 0 / var:1 olarak değerlendirilmiştir. Toplumda gözlenen apse oluşumu Brothwell (1981)'in geliştirmiş olduğu yönteme göre; 0:Yok, 1: Az, 2:Orta 3: İleri olarak derecelendirilmiştir. Alveol kemik kaybı oranını belirlemek için Brothwell'in (1981) geliştirdiği yöntem (0: yok, 1: az, 2: orta, 3: ileri) kullanılmıştır.

\section{Istatistiksel Yöntem}

Diş çürüğü, diş taşı, aşınma, hipoplasya, apse, alveol kemik kaybı, antemortem diş kaybı açısından incelenen dişlerden elde edilen veriler SPSS 22.0 programina girilerek istatistik değerlendirmeleri yapılmıştır. Veri Analizi SPSS (Versiyon 22.0, SPSS Inc., Chicago, IL, USA, Hitit Üniversitesi Lisans1) paket programı ile yapılmıştır. Tanımlayıcı istatistikler kategorik değişkenler için say1 ve yüzde (\%) olarak sunulmuştur. Kategorik değişkenlerden; Cinsiyet, Yaş ve Diş grupları ile Çürük, Apse, Alveol kaybı, hipoplasya vb. arasındaki ilişki araştırmaları ve oran karşılaştırmaları için varsayımlara uygun olarak Ki-Kare (Cbi-Square) veya Fisher Kesin KiKare (Fisher exact test) kullanılmıştır. $\mathrm{P}<0.05$ istatistiksel olarak anlamlı farklı olarak kabul edilmiştir (Demir, 2018; Comba vd., 2019). İstatistiksel değerlendirmeler Hitit Üniversitesi Dr. Öğr. Üyesi Emre Demir tarafindan yapılmıştır.

\section{Bulgular ve Değerlendirme Diş Çürüğü}

Akgüney toplumuna ait 625 diş, diş çürüğü açısından incelenmiştir. Yapılan incelemeler sonucunda düzeltilmemiş çürük oranı $\% 9,12$ olarak tespit edilmiştir (Tablo 4) (Resim 1). Diş çürüğü oranı alt çenede $\% 9,84$ iken, üst çenede \%8,03 olarak bulunmuştur. Çürük oranı kadin bireylerde $\% 8,75$, erkek bireylerde $\% 8,52$, adölesan bireylerde $\% 9,09$, bebeklerde ise $\% 4$ olarak tespit edilirken, izole dişlerde çürük oranı $\% 13,47$ olarak belirlenmiştir. Çocuklarda toplam diş çürügü oranı $\%$ 4,65 olarak tespit edilmiştir. Çocuk süt dişlerinde diş çürüğü oranı $\% 2,94$, çocukların daimi dişlerde diş çürüğü oranı ise \%11,11 olarak bulunmuştur. Akgüney toplumunda süt dişlerde toplam diş çürüğü oran $1 \% 3,57$ iken, daimi dişlerde diş çürüğü oranı ise \%9,98'dir.

Toplum genelinde diş çürüğ̈ oluşumundan en çok etkilenen diş grubunun \%18,26 oranla 2. molar olduğu görülmektedir. 1. molarda diş çürüğü oranı $\% 15,23,3$. molarda diş çürüğü oranı ise $\% 15,68$ olarak tespit edilmiştir (Tablo 4). Arka dişlerin morfolojik yapılarından dolayı diş çürüğünden daha fazla etkilendiği bilinmektedir. $\mathrm{Bu}$ durum Akgüney Toplumunda da gözlenmiştir, ön dişlerde çürük oranı daha az görülürken, arka dişlerde çürük oranları daha yüksektir.

Akgüney toplumu kadın ve erkek bireylerde görülen diş çürük oranları istatiksel olarak değerlendirilmiştir. Erkek bireylerle kadın bireylerde görülen diş çürük oranları birbirine oldukça yakın değerlerdedir. İstatiksel olarak değerlendirildiğinde çürük oranının cinsiyetler arasında istatiksel olarak anlamlı bir fark görülmediği tespit edilmiştir ( $\mathrm{p}=0.951$ ) (Tablo 5).

Kadın ve erkek bireylerde diş çürügü yaş grupları açısından değerlendirilmiştir. Yaş grupları açısından bakıldığında diş çürügü açısından istatiksel olarak anlamlı bir fark olduğu görülmüştür $(\mathrm{p}=0.031)$. İleri erişkin bireylerde diş çürüğü oranı daha yüksektir $(\% 15,9)$. Diş çürügü oranı genç erişkin bireylerde \% $\%, 9$ iken, orta erişkin bireylerde \%4,1dir. Yaşı tam olarak tespit edilemeyen erişkin bireylerde ise \%8,8'dir (Tablo 6).

Kadın ve erkek bireylerde diş çürüğü diş grupları açısından değerlendirilmiştir. Yapılan değerlendirmeye göre, diş grupları arasında çürük oluşumu açısından istatistiksel olarak anlamlı fark bulunmuștur 
Şarbak | Antropoloji 38 (2019), 5-19

Tablo 4. Akgüney toplumunda çeneye göre diş çürüğü dağılımı

\begin{tabular}{cccccccccc}
\hline & \multicolumn{3}{c}{ Alt Çene } & \multicolumn{3}{c}{ Üst Çene } & \multicolumn{3}{c}{ Toplam } \\
ÇÜRÜK & B & G & \% & B & G & \% & B & G & \% \\
\hline I1 & 25 & 1 & 4 & 26 & 0 & 0 & $\mathbf{5 1}$ & $\mathbf{1}$ & $\mathbf{1 , 9 6}$ \\
I2 & 43 & 1 & 2,32 & 25 & 1 & 4 & $\mathbf{6 8}$ & $\mathbf{2}$ & $\mathbf{2 , 9 4}$ \\
C & 50 & 1 & 2 & 45 & 1 & 2,22 & $\mathbf{9 5}$ & $\mathbf{2}$ & $\mathbf{2 , 1}$ \\
P1 & 48 & 1 & 2,08 & 32 & 4 & 12,5 & $\mathbf{8 0}$ & $\mathbf{5}$ & $\mathbf{6 , 2 5}$ \\
P2 & 41 & 1 & 2,43 & 26 & 2 & 7,69 & $\mathbf{6 7}$ & $\mathbf{3}$ & $\mathbf{4 , 4 7}$ \\
M1 & 68 & 13 & 19,11 & 35 & 3 & 8,57 & $\mathbf{1 0 3}$ & $\mathbf{1 6}$ & $\mathbf{1 5 , 5 3}$ \\
M2 & 69 & 14 & 20,28 & 35 & 5 & 14,28 & $\mathbf{1 0 4}$ & $\mathbf{1 9}$ & $\mathbf{1 8 , 2 6}$ \\
M3 & 32 & 5 & 15,62 & 25 & 4 & 16 & $\mathbf{5 7}$ & $\mathbf{9}$ & $\mathbf{1 5 , 6 8}$ \\
TOPLAM & $\mathbf{3 7 6}$ & $\mathbf{3 7}$ & $\mathbf{9 , 8 4}$ & $\mathbf{2 4 9}$ & $\mathbf{2 0}$ & $\mathbf{8 , 0 3}$ & $\mathbf{6 2 5}$ & $\mathbf{5 7}$ & $\mathbf{9 , 1 2}$ \\
\hline
\end{tabular}

Tablo 5. Akgüney toplumunda cinsiyete göre diş çürüğü dağılımı

\begin{tabular}{llcccc}
\hline \multirow{2}{*}{ CINSIYYT } & \multicolumn{2}{c}{ ÇÜRÜK } & \multirow{2}{*}{ Toplam } \\
& \multirow{2}{*}{ Erkek } & $\mathrm{n}$ & 118 & 11 & $\mathbf{1 2 9}$ \\
& \multirow{2}{*}{ Kadın } & $\%$ & 91,5 & 8,5 & $\mathbf{1 0 0}$ \\
& & $\mathrm{n}$ & 220 & 21 & $\mathbf{2 4 1}$ \\
& $\mathbf{n}$ & & 91,3 & 8,7 & $\mathbf{1 0 0}$ \\
\multirow{2}{*}{ TOPLAM } & Cinsiyet & & $\mathbf{3 3 8}$ & $\mathbf{3 2}$ & $\mathbf{3 7 0}$ \\
& & & $\mathbf{9 1 , 4}$ & $\mathbf{8 , 6}$ & $\mathbf{1 0 0}$ \\
\hline
\end{tabular}

Tablo 6. Akgüney toplumunda yaş gruplarına göre diş çürügü dağılımı (Kadın+Erkek)

\begin{tabular}{|c|c|c|c|c|}
\hline \multirow{2}{*}{ YAŞ } & & \multicolumn{2}{|c|}{ ÇÜRÜK } & \multirow{2}{*}{ Toplam } \\
\hline & & Yok & Var & \\
\hline \multirow{2}{*}{ Genç Erişkin } & $\mathrm{n}$ & 111 & 7 & 118 \\
\hline & $\%$ & $94,1 \%$ & $5,9 \%$ & $100,0 \%$ \\
\hline \multirow{2}{*}{ Orta Erişkin } & $\mathrm{n}$ & 70 & 3 & 73 \\
\hline & $\%$ & $95,9 \%$ & $4,1 \%$ & $100,0 \%$ \\
\hline \multirow{2}{*}{ İleri Erişkin } & $\mathrm{n}$ & 74 & 14 & 88 \\
\hline & $\%$ & $84,1 \%$ & $15,9 \%$ & $100,0 \%$ \\
\hline \multirow{2}{*}{ Erişkin } & $\mathrm{n}$ & 83 & 8 & 91 \\
\hline & $\%$ & $91,2 \%$ & $8,8 \%$ & $100,0 \%$ \\
\hline \multirow{2}{*}{ TOPLAM } & $\mathrm{n}$ & 338 & 32 & 370 \\
\hline & $\%$ & $91,4 \%$ & $8,6 \%$ & $100,0 \%$ \\
\hline
\end{tabular}

$(p=0.003)$. En fazla çürük oluşumunun 1. molarda olduğu görülmektedir (Tablo 7). İstatiksel olarak değerlendirildiğinde çürük oranının cinsiyetler arasında istatiksel olarak anlamlı bir fark görülmediği tespit edilmiştir ( $\mathrm{p}=0.951)$ (Tablo 5).

Kadın ve erkek bireylerde diş çürüğü yaş grupları açısından değerlendirilmiştir. Yaş grupları açısından bakıldığında diş çürüğü açısından istatiksel olarak anlamlı bir fark olduğu görülmüştür $(\mathrm{p}=0.031)$. İleri erişkin bireylerde diş çürügü oranın daha yüksektir $(\% 15,9)$. Diş çürüğü oranı genç erişkin bireylerde \% $\%, 9$ iken, orta erişkin bireylerde \%4,1dir. Yaşı tam olarak tespit edilemeyen erişkin bireylerde ise \%8,8'dir (Tablo 6).

\section{Diş Taşı}

Akgüney Toplumu bireylerine ait 631 dişin 583’ü diş taşı açısından incelenmiş ve toplumdaki diş taşı oranı $\% 28,98$ olarak bulunmuştur (Tablo 6). Alt çenede toplam diş taşı oranı $\% 29,26$, erkek bireylerde $\% 51,61$, adölesan bireylerde $\% 68,18$, çocuklarda $\% 2,32$ olarak tespit edilmiştir. İzole dişlerdeki diş taşı oranı ise $\% 20$ ,86'dır. Bebeklerde ise diş taşına rastlanmamıştır. Akgüney Toplumu dişlerinde diş taşının en yoğun olan 
Tablo 7. Akgüney toplumu diş grupları açısından diş çürügü dağılımları (Kadın+Erkek)

\begin{tabular}{|c|c|c|c|c|}
\hline \multirow{2}{*}{ Diş Grupları } & & \multicolumn{2}{|c|}{ ÇÜRÜK } & \multirow{2}{*}{ Toplam } \\
\hline & & Yok & Var & \\
\hline \multirow{2}{*}{ I1 } & $\mathrm{n}$ & 25 & 0 & 25 \\
\hline & $\%$ & 100,0 & 0,0 & 100,0 \\
\hline \multirow{2}{*}{$\mathrm{I} 2$} & $\mathrm{n}$ & 37 & 1 & 38 \\
\hline & $\%$ & 97,4 & 2,6 & 100,0 \\
\hline \multirow{2}{*}{ C } & $\mathrm{n}$ & 53 & 1 & 54 \\
\hline & $\%$ & 98,1 & 1,9 & 100,0 \\
\hline \multirow{2}{*}{ PM1 } & $\mathrm{n}$ & 52 & 4 & 56 \\
\hline & $\%$ & 92,9 & 7,1 & 100,0 \\
\hline \multirow{2}{*}{ PM2 } & $\mathrm{n}$ & 50 & 2 & 52 \\
\hline & $\%$ & 96,2 & 3,8 & 100,0 \\
\hline \multirow{2}{*}{ M1 } & $\mathrm{n}$ & 43 & 11 & 54 \\
\hline & $\%$ & 79,6 & 20,4 & 100,0 \\
\hline \multirow{2}{*}{ M2 } & $\mathrm{n}$ & 44 & 8 & 52 \\
\hline & $\%$ & 84,6 & 15,4 & 100,0 \\
\hline \multirow{2}{*}{ M3 } & $\mathrm{n}$ & 34 & 5 & 39 \\
\hline & $\%$ & 87,2 & 12,8 & 100,0 \\
\hline \multirow{2}{*}{ Toplam } & $n$ & 338 & 32 & 370 \\
\hline & $\%$ & 91,4 & 8,6 & 100,0 \\
\hline
\end{tabular}

diş grubunun ön dişler olduğu görülmektedir. Arka dişlerde diş taşı oranı daha az olduğu görülmektedir (Tablo 8).

Kadın ve erkek bireylerde görülen diş taşı oranları istatistiksel açıdan değerlendirilmiştir. Akgüney toplumunda cinsiyetler arasinda istatiksel açısından anlamlı fark olduğu görülmüştür $(\mathrm{p}<0,001)$. Erkek bireylerde diş taşı oranı $(51,4 \%)$ kadın bireylere $(\% 29,26)$ göre daha fazladır (Tablo 9).

Kadın ve erkek bireylerde gözlemlenen diş taşı yaş grupları açısından istatiksel olarak değerlendirilmiştir. Yapılan değerlendirmeler sonucunda Yaş gruplarına göre diş taşı oluşumu açısından istatistiksel olarak anlamlı fark $(\mathrm{p}<0,001)$ olduğu tespit edilmiştir. İleri erişkin bireylerde diş taşı oranının daha yüksek olduğu tespit edilmiştir (Tablo 10).

\section{Hipoplasya}

Akgüney Toplumuna ait toplam 469 diş hipoplasya açısından incelenmiştir. Yapılan değerlendirmeler sonucunda toplumdaki hipoplasya oran1 \%40,29 olarak belirlenmiştir (Tablo 11). Hipoplasya görülme sıklı̆g alt çenede $\% 31,67$, üst çenede ise $\% 51,2$ olarak tespit edilmiştir. Hipoplasya görülme sıklı̆̆1 diş grupları açısından incelendiğinde birinci insisiv hipoplasya oranının en yüksek görüldüğü diş grubu olmuştur. İkinci insisivde hipoplasya görülme oranı $\% 46,8$ iken caninde hipoplasya görülme oranı \%53,42 olarak bulunmuştur.
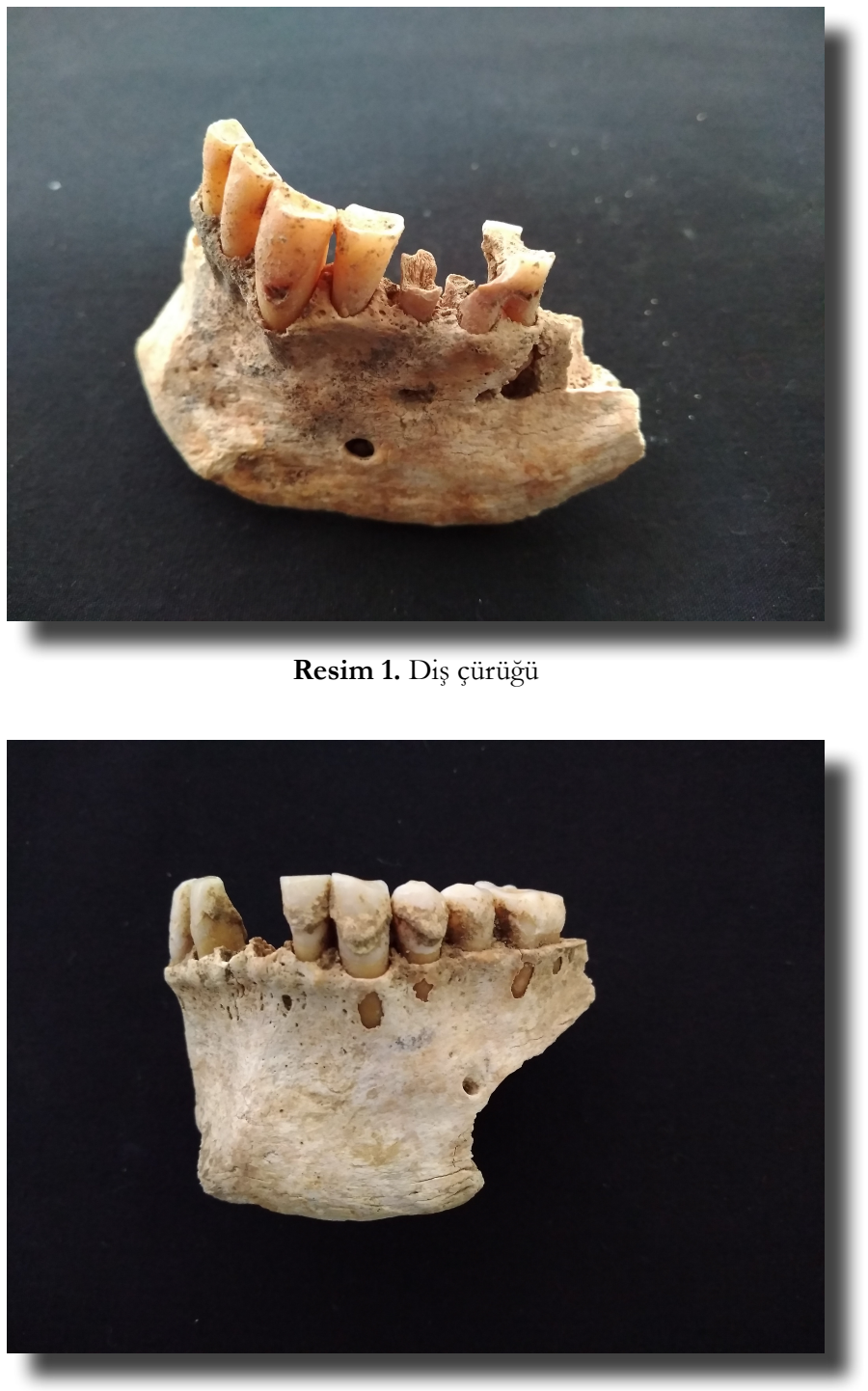

Resim 2. Diş taşı

Alt çenede hipoplasya en s1k üçüncü molarda tespit edilirken, üst çenede görülme oranının en çok olduğu diş grubu birinci insisiv olmuştur (Tablo 11).

Akgüney toplumu kadin bireylerinde hipoplasya görülme sılklğ $1 \% 38$, erkek bireylerde $\% 33$, izole dişlerde $\% 58,33$, adölesan bireylerde ise $\% 22,72$ olarak belirlenmiştir. Çocukların daimi dişlerinde hipoplasya görülme sıklı̆̆ $\% 22,22$ iken, süt dişlerinde görülme s1klığ1 ise \%23,33’tür. Bebeklerde hipoplasya görülme sıklığ1 \%37,10 olarak tespit edilmiştir. Bebeklerde hipoplasya görülme yaşı ise 2-2,5 yaş aralığı olarak belirlenmiştir.

Akgüney toplumu kadın ve erkek bireylerde görülen hipoplasya oluşumu istatiksel açıdan değerlendirilmiştir. Yapılan istatiksel değerlendirmeler sonucunda cinsiyetler arasında hipoplasya oluşumu açısından anlamlı bir farkın olmadığı sonucuna ulaşılmıştır $(\mathrm{p}=0,552)$.Yaş gruplarına göre hipoplasya oluşumu açısından istatistiksel olarak anlamlı fark olmadığı belirlenmiştir (Tablo 12).

Akgüney toplumu kadın ve erkek bireylerinde gözlemlenen hipoplasya diş grupları açısından istatiksel 
Tablo 8. Akgüney toplumunda çeneye göre diş taşı dağılımı

\begin{tabular}{cccccccccc}
\hline & \multicolumn{3}{c}{ Alt Çene } & \multicolumn{3}{c}{ Üst Çene } & \multicolumn{3}{c}{ Toplam } \\
DİŞ TAŞI & B & G & $\mathbf{0}$ & B & G & $\mathbf{\%}$ & B & G & \% \\
\hline I1 & 21 & 9 & 42,85 & 26 & 9 & 34,61 & 47 & $\mathbf{1 8}$ & $\mathbf{3 8 , 2 9}$ \\
I2 & 39 & 18 & 46,15 & 23 & 9 & 39,13 & $\mathbf{6 2}$ & $\mathbf{2 7}$ & $\mathbf{4 3 , 5 4}$ \\
C & 46 & 18 & 39,13 & 46 & 14 & 30,43 & $\mathbf{9 2}$ & $\mathbf{3 2}$ & $\mathbf{3 4 , 7 8}$ \\
P1 & 42 & 11 & 26,19 & 29 & 10 & 34,48 & $\mathbf{7 1}$ & $\mathbf{2 1}$ & $\mathbf{2 9 , 5 7}$ \\
P2 & 31 & 8 & 25,8 & 24 & 9 & 37,5 & $\mathbf{5 5}$ & $\mathbf{1 7}$ & $\mathbf{3 0 , 9}$ \\
M1 & 64 & 8 & 12,5 & 35 & 9 & 25,71 & $\mathbf{9 9}$ & $\mathbf{1 7}$ & $\mathbf{1 7 , 1 7}$ \\
M2 & 67 & 15 & 22,38 & 35 & 5 & 14,28 & $\mathbf{1 0 2}$ & $\mathbf{2 0}$ & $\mathbf{1 9 , 6}$ \\
M3 & 29 & 12 & 41,37 & 26 & 5 & 19,23 & $\mathbf{5 5}$ & $\mathbf{1 7}$ & $\mathbf{3 0 , 9}$ \\
TOPLAM & $\mathbf{3 3 9}$ & $\mathbf{9 9}$ & $\mathbf{2 9 , 2}$ & $\mathbf{2 4 4}$ & $\mathbf{7 0}$ & $\mathbf{2 8 , 6 8}$ & $\mathbf{5 8 3}$ & $\mathbf{1 6 9}$ & $\mathbf{2 8 , 9 8}$ \\
\hline
\end{tabular}

Tablo 9. Akgüney toplumunda cinsiyete göre diş taşı dağıllımı

\begin{tabular}{llcccc}
\hline \multirow{2}{*}{ CINSIYET } & \multicolumn{2}{c}{ DİŞ TAŞI } & \multirow{2}{*}{ Toplam } \\
\cline { 3 - 5 } & \multirow{2}{*}{ Erkek } & $\mathrm{n}$ & 60 & 64 & $\mathbf{1 2 4}$ \\
& & $\%$ & 48,39 & 51,61 & $\mathbf{1 0 0 , 0}$ \\
& \multirow{2}{*}{ Kadin } & $\mathrm{n}$ & 145 & 60 & $\mathbf{2 0 5}$ \\
& & $\%$ & 70,74 & 29,26 & $\mathbf{1 0 0 , 0}$ \\
\multirow{2}{*}{ TOPLAM } & $\mathbf{n}$ & & $\mathbf{2 0 4}$ & $\mathbf{1 2 6}$ & $\mathbf{3 3 0}$ \\
& Cinsiyet & & $\mathbf{6 1 , 8}$ & $\mathbf{3 8 , 2}$ & $\mathbf{1 0 0 , 0}$ \\
\hline
\end{tabular}

Tablo 10. Akgüney toplumunda yaş gruplarına göre diş taşı dağılımı (Kadın+Erkek)

\begin{tabular}{|c|c|c|c|c|}
\hline \multirow{2}{*}{ YAŞ } & & \multicolumn{2}{|c|}{ DİŞ TAŞI } & \multirow{2}{*}{ Toplam } \\
\hline & & Yok & Var & \\
\hline \multirow{2}{*}{ Genç Erişkin } & $\mathrm{n}$ & 66 & 18 & 84 \\
\hline & $\%$ & 78,6 & 21,4 & 100,0 \\
\hline \multirow{2}{*}{ Orta Erişkin } & $\mathrm{n}$ & 43 & 30 & 73 \\
\hline & $\%$ & 58,9 & 41,1 & 100,0 \\
\hline \multirow{2}{*}{ İleri Erişkin } & $\mathrm{n}$ & 36 & 51 & 87 \\
\hline & $\%$ & 41,4 & 58,6 & 100,0 \\
\hline \multirow{2}{*}{ Erişkin } & $\mathrm{n}$ & 59 & 27 & 86 \\
\hline & $\%$ & 68,6 & 31,4 & 100,0 \\
\hline \multirow{2}{*}{ TOPLAM } & $\mathbf{n}$ & 204 & 126 & 330 \\
\hline & $\%$ & 61,8 & 38,2 & 100,0 \\
\hline
\end{tabular}

olarak değerlendirilmiştir. Yapılan değerlendirmeler sonucunda diş gruplanı arasında hipoplasya oluşumu açısından istatiksel olarak anlamlı fark olduğu tespit edilmiştir $(\mathrm{p}<0,001)$. Diş grupları arasında hipoplasyadan en çok etkilenen dişin $\% 73,5$ oranla kanin dişler olduğu görülmektedir. Hipoplasyadan en az etkilenen diş gruplar1 ise $\% 6,7$ oranla ikinci premolar olmuştur (Tablo 13).

\section{Diş Aşınması}

Akgüney toplumuna ait 631 dişin 619'u diş aşınması açısından incelenmiştir. Diş aşınma derecelendirmesinde 1. derece "aşınma yok" olarak kabul edilmiştir. Bu doğrultuda bakıldığında en sık aşınma derecesi \%21,64 oranla 3. derece aşınma olduğu görülmektedir. Toplumdaki dişlerin \%38,29'unda ise aşınma gözlenmemiştir. Toplumda ileri derece aşınmaların oranının az olduğu görülmektedir. Toplumda az ve orta dereceli aşınmaların oranını daha yüksektir (Tablo 14). Pulpaya inen aşınma oranı ise $\% 5,3$ olarak tespit edilmiştir.

Kadın ve erkek bireylerdeki aşınma istatiksel açıdan değerlendirilmiştir. Buna göre kadın ve erkekler bireylerde aşınma oluşumu açısından istatistiksel olarak anlamlı fark olduğu bulunmuştur $(p<0,001)$. Kadın bireylerin dişleri \%70,6 oranında aşınırken erkek 
Tablo 11. Akgüney toplumunda çeneye göre hipoplasya dağıllımı

\begin{tabular}{cccccccccc}
\hline & \multicolumn{3}{c}{ Alt Çene } & \multicolumn{3}{c}{ Üst Çene } & \multicolumn{3}{c}{ Toplam } \\
HİPOPLASYA & B & G & $\mathbf{0}$ & B & G & $\mathbf{\%}$ & B & G & \% \\
\hline I1 & 12 & 2 & 16,66 & 23 & 21 & 91,3 & $\mathbf{3 5}$ & $\mathbf{2 3}$ & $\mathbf{6 5 , 7 1}$ \\
I2 & 28 & 8 & 28,57 & 19 & 14 & 73,68 & $\mathbf{4 7}$ & $\mathbf{2 2}$ & $\mathbf{4 6 , 8}$ \\
C & 36 & 20 & 55,55 & 37 & 19 & 51,35 & $\mathbf{7 3}$ & $\mathbf{3 9}$ & $\mathbf{5 3 , 4 2}$ \\
P1 & 35 & 3 & 8,57 & 24 & 10 & 41,66 & $\mathbf{5 9}$ & $\mathbf{1 3}$ & $\mathbf{2 2 , 0 3}$ \\
P2 & 24 & 1 & 4,16 & 16 & 2 & 12,5 & $\mathbf{4 0}$ & $\mathbf{3}$ & $\mathbf{7 , 5}$ \\
M1 & 49 & 13 & 26,53 & 33 & 12 & 36,36 & $\mathbf{8 2}$ & $\mathbf{2 5}$ & $\mathbf{3 0 , 4 8}$ \\
M2 & 52 & 21 & 41,17 & 30 & 16 & 53,33 & $\mathbf{8 2}$ & $\mathbf{3 7}$ & $\mathbf{4 5 , 1 2}$ \\
M3 & 26 & 15 & 57,69 & 25 & 12 & 48 & $\mathbf{5 1}$ & $\mathbf{2 7}$ & $\mathbf{5 2 , 9 4}$ \\
TOPLAM & $\mathbf{2 6 2}$ & $\mathbf{8 3}$ & $\mathbf{3 1 , 6 7}$ & $\mathbf{2 0 7}$ & $\mathbf{1 0 6}$ & $\mathbf{5 1 , 2}$ & $\mathbf{4 6 9}$ & $\mathbf{1 8 9}$ & $\mathbf{4 0 , 2 9}$ \\
\hline
\end{tabular}

Tablo 12. Akgüney toplumunda cinsiyete göre hipoplasya dağılımı

\begin{tabular}{lccccc}
\hline \multirow{2}{*}{ CINSIYYT } & \multicolumn{2}{c}{ HİPOPLASYA } & \multirow{2}{*}{ Toplam } \\
& \multirow{2}{*}{ Erkek } & $\mathrm{n}$ & Yok & Var & \\
\hline \multirow{6}{*}{ Kadin } & $\%$ & 67 & 33 & $\mathbf{1 0 0}$ \\
& & $\mathrm{n}$ & 93 & 33,0 & $\mathbf{1 0 0 , 0}$ \\
& & $\%$ & 62 & 38 & $\mathbf{1 5 0}$ \\
\multirow{2}{*}{ TOPLAM } & $\mathbf{n}$ & & $\mathbf{1 6 0}$ & $\mathbf{9 0}$ & $\mathbf{2 5 0}$ \\
& Cinsiyet & & $\mathbf{6 4}$ & $\mathbf{3 6}$ & $\mathbf{1 0 0 , 0}$ \\
\hline
\end{tabular}

Tablo 13. Akgüney toplumunda yaş gruplarına göre hipoplasya dağılımı (Kadın+Erkek)

\begin{tabular}{ccccc}
\hline \multirow{2}{*}{ YAŞ } & \multicolumn{3}{c}{ HİPOPLASYA } & \multirow{2}{*}{ Toplam } \\
& & Yok & Var & \\
\hline \multirow{2}{*}{ Genç Erişkin } & $\mathrm{n}$ & 66 & 18 & $\mathbf{8 4}$ \\
& $\%$ & 78,6 & 21,4 & $\mathbf{1 0 0 , 0}$ \\
Orta Erişkin & $\mathrm{n}$ & 43 & 30 & $\mathbf{7 3}$ \\
& $\%$ & 58,9 & 41,1 & $\mathbf{1 0 0 , 0}$ \\
İleri Erişkin & $\mathrm{n}$ & 36 & 51 & $\mathbf{8 7}$ \\
\multirow{2}{*}{ Erişkin } & $\%$ & 41,4 & 58,6 & $\mathbf{1 0 0 , 0}$ \\
& $\mathrm{n}$ & 59 & 27 & $\mathbf{8 6}$ \\
TOPLAM & $\%$ & 68,6 & 31,4 & $\mathbf{1 0 0 , 0}$ \\
& $\mathbf{n}$ & $\mathbf{2 0 4}$ & $\mathbf{1 2 6}$ & $\mathbf{3 3 0}$ \\
& $\mathbf{\%}$ & $\mathbf{6 1 , 8}$ & $\mathbf{3 8 , 2}$ & $\mathbf{1 0 0 , 0}$ \\
\hline
\end{tabular}

bireylerin dişlerinde ise \% $\% 93,7$ oranında aşınma tespit edilmiştir (Tablo 15).

Kadın ve erken bireylerin dişlerindeki aşınma görülme oranları yaş grupları açısından istatiksel olarak anlamlı fark olduğu belirlenmiştir $(p<0.001)$. Genç erişkin bireylerde aşınma görülme oranı daha az iken orta ve ileri erişkin bireylerin dişlerinde aşınma oranı daha yüksektir (Tablo 16).

\section{Antemortem Diş Kaybı}

Akgüney toplumunda antemortem diş kab1 oran1 $\% 7,82$ olarak bulunmuştur. $\mathrm{Bu}$ oran kadın bireylerde $\% 8,78$, erkek bireylerde \%6,73'tür. Alt çenede antemortem oranı $\% 8,9$ iken, üst çenede $\% 5,31$ olarak tespit edilmiştir. Diş grupları arasındaki antemortem diş kayb1 sıklığına bakıldığında ise $\% 18,86$ oranla en çok 3. molarlarda olduğu görülürken, ikinci sırada \%13,33 oranla 1. molar yer almaktadır. Kanin dişlerde ise antemortem diş kaybına rastlanılmamıştır (Tablo 17). İzole çenelerde antemortem diş kaybı oranı ise $\% 22$ olarak belirlenirken, bebek ve çocuklarda antemortem diş kaybı gözlenmemiştir.

İstatiksel olarak kadın ve erkek bireylerde arasında antemortem kaybı açısından anlamlı fark bulunamamıştır $(\mathrm{p}=0,375)$ (Tablo 18). Yaş grupları arasında antemortem diş kaybı istatistiksel açıdan anlamlı değildir $(p=0,091)$ (Tablo 19). 


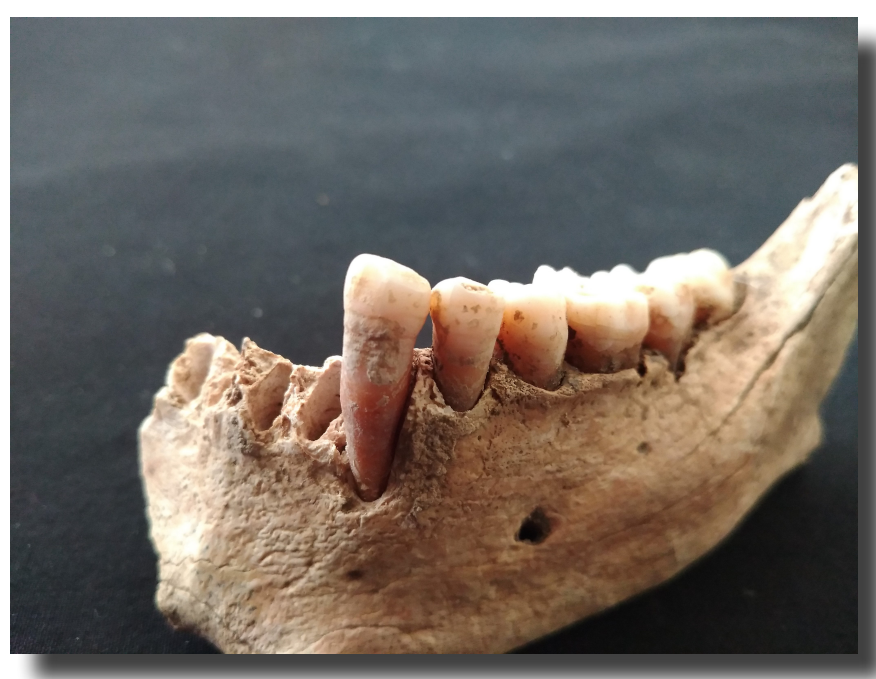

Resim 3. Hipoplasya

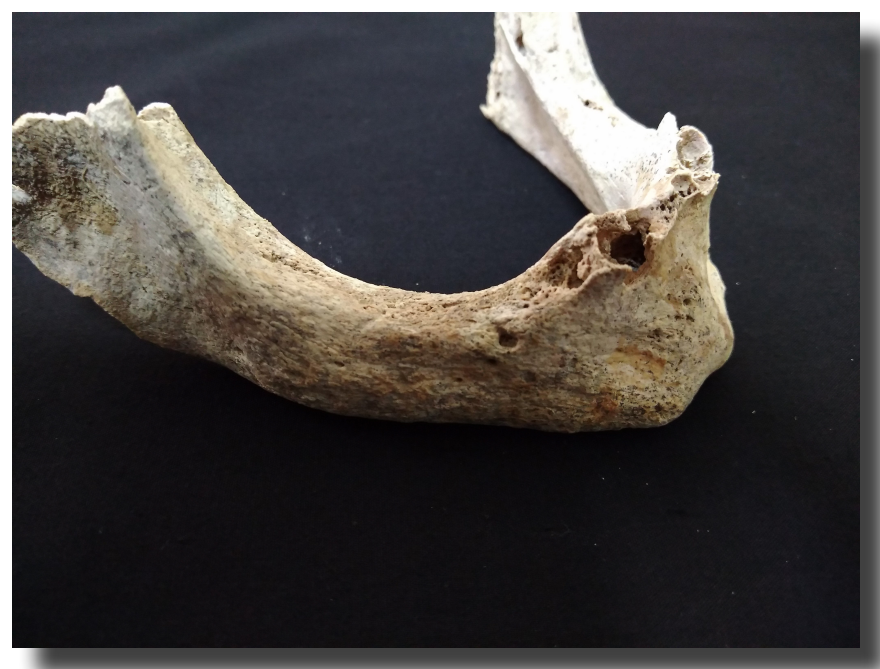

Resim 5. Antemortem diş kaybı

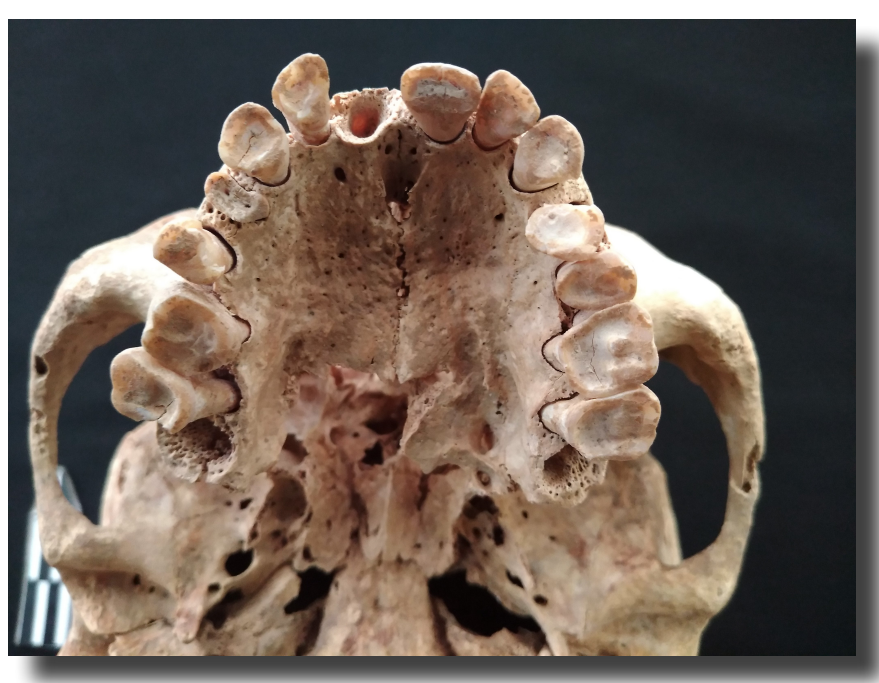

Resim 4. Diş aşınması

Tablo 15. Akgüney toplumunda cinsiyete göre aşınma oranları

\begin{tabular}{llcccc}
\hline \multirow{2}{*}{ CINSIYET } & \multicolumn{2}{c}{ AŞINMA } & \multirow{2}{*}{ Toplam } \\
& \multirow{2}{*}{ Erkek } & $\mathrm{n}$ & 8 & 119 & $\mathbf{1 2 7}$ \\
& \multirow{2}{*}{ Kok } & Var & \\
& & $\%$ & 6,3 & 93,7 & $\mathbf{1 0 0 , 0}$ \\
& \multirow{2}{*}{ Kadin } & $\mathrm{n}$ & 70 & 168 & $\mathbf{2 3 8}$ \\
& & $\%$ & 29,4 & 70,6 & $\mathbf{1 0 0 , 0}$ \\
\multirow{2}{*}{ TOPLAM } & $\mathbf{n}$ & & $\mathbf{7 8}$ & $\mathbf{2 8 7}$ & $\mathbf{3 6 5}$ \\
& Cinsiyet & & $\mathbf{2 1 , 4}$ & $\mathbf{7 8 , 6}$ & $\mathbf{1 0 0 , 0}$ \\
\hline
\end{tabular}

Tablo 14. Akgüney toplumunda aşınma dereceleri dağılımı

\begin{tabular}{ccc}
\hline Aşınma Derecesi & $\mathbf{n}$ & $\mathbf{\%}$ \\
\hline $\mathbf{1}$ & 237 & 38,29 \\
$\mathbf{2}$ & 99 & 15,99 \\
$\mathbf{2 +}$ & 37 & 5,98 \\
$\mathbf{3}$ & 134 & 21,64 \\
$\mathbf{3 +}$ & 19 & 3,07 \\
$\mathbf{4}$ & 49 & 7,92 \\
$\mathbf{4 +}$ & 9 & 1,46 \\
$\mathbf{5}$ & 10 & 1,61 \\
$\mathbf{5 +}$ & 3 & 0,49 \\
$\mathbf{5 + +}$ & 2 & 0,32 \\
$\mathbf{6}$ & 17 & 2,74 \\
$\mathbf{7}$ & 3 & 0,49 \\
TOPLAM & $\mathbf{6 1 9}$ & $\mathbf{1 0 0}$ \\
\hline
\end{tabular}

Tablo 16. Akgüney toplumunda yaş gruplarına göre aşınma oranları (Kadın+Erkek)

\begin{tabular}{|c|c|c|c|c|}
\hline \multirow{2}{*}{ YAŞ } & & \multicolumn{2}{|c|}{ AŞINMA } & \multirow{2}{*}{ Toplam } \\
\hline & & Yok & Var & \\
\hline \multirow{2}{*}{ Genç Erişkin } & $\mathrm{n}$ & 69 & 49 & 118 \\
\hline & $\%$ & 58,5 & 41,5 & 100,0 \\
\hline \multirow{2}{*}{ Orta Erişkin } & $\mathrm{n}$ & 4 & 69 & 73 \\
\hline & $\%$ & 5,5 & 94,5 & 100,0 \\
\hline \multirow{2}{*}{ İleri Erişkin } & $\mathrm{n}$ & 0 & 86 & 86 \\
\hline & $\%$ & 0,0 & 100,0 & 100,0 \\
\hline \multirow{2}{*}{ Erişkin } & $\mathrm{n}$ & 5 & 83 & 88 \\
\hline & $\%$ & 5,7 & 94,3 & 100,0 \\
\hline \multirow{2}{*}{ TOPLAM } & $\mathrm{n}$ & 78 & 287 & 365 \\
\hline & $\%$ & 21,4 & 78,6 & 100,0 \\
\hline
\end{tabular}




\section{Apse}

Akgüney toplumunda apse oranı \%1,16 olarak tespit edilmiştir. Kadın bireylerde apse oranı \%1,09 iken, erkek bireylerde apse oranı \%2,11'dir. Bebek ve çocuk bireylerde apse olgusuna rastlanmamıştır. Apse oranı alt çenede $\% 1,14$, üst çenede ise $\% 1,2$ olarak bulunmuştur. Apse diş grupları açısından incelendiğinde ise en çok apse görülen diş \%3,19 oranla 1. molardır. Çürük oluşumu da en çok arka dişleri etkilediği göz önüne alındığında apsenin de en çok arka dişleri etkilemiş olması şaşırtıcı değildir. Ön dişlerde apse olgusu tespit edilmemiştir (Tablo 20).

Kadın ve erkek bireylerde apse açısından istatiksel olarak anlamlı bir fark bulunamamıştır $(\mathrm{p}=0,242)$ (Tablo 21). Aynı şekilde yaş grupları arasında apse oluşumu açısından da istatiksel olarak anlamlı fark yoktur $(p=0,104)$ (Tablo 22).

\section{Alveol Kemik Kaybı}

Akgüney Toplumu alveol kemik kaybı oranı \% 41,43

Tablo 17. Akgüney toplumunda çeneye göre antemortem diş kaybı dağılımı

\begin{tabular}{|c|c|c|c|c|c|c|c|c|c|}
\hline \multirow{2}{*}{$\begin{array}{c}\text { ANTEMORTEM } \\
\text { DİŞ KAYBI }\end{array}$} & \multicolumn{3}{|c|}{ Alt Çene } & \multicolumn{3}{|c|}{ Üst Çene } & \multicolumn{3}{|c|}{ Toplam } \\
\hline & B & G & $\%$ & B & G & $\%$ & B & G & $\%$ \\
\hline I1 & 62 & 5 & 8,06 & 27 & 0 & 0 & 89 & 5 & 5,61 \\
\hline I2 & 61 & 2 & 3,27 & 25 & 0 & 0 & 86 & 2 & 2,32 \\
\hline $\mathrm{C}$ & 63 & 0 & 0 & 31 & 0 & 0 & 94 & 0 & 0 \\
\hline P1 & 59 & 2 & 3,38 & 30 & 2 & 6,66 & 89 & 4 & 4,49 \\
\hline P2 & 59 & 7 & 11,86 & 30 & 3 & 10 & 89 & 10 & 11,23 \\
\hline M1 & 77 & 12 & 15,58 & 28 & 2 & 7,14 & 105 & 14 & 13,33 \\
\hline M2 & 63 & 7 & 11,11 & 22 & 2 & 9,09 & 85 & 9 & 10,58 \\
\hline M3 & 39 & 8 & 20,51 & 14 & 2 & 14,28 & 53 & 10 & 18,86 \\
\hline TOPLAM & 483 & 43 & 8,9 & 207 & 11 & 5,31 & 690 & 54 & 7,82 \\
\hline
\end{tabular}

Tablo 18. Akgüney toplumunda cinsiyete göre antemortem diş kaybı dağılımı

\begin{tabular}{|c|c|c|c|c|c|}
\hline & \multirow{2}{*}{\multicolumn{2}{|c|}{ CINSIYET }} & \multicolumn{2}{|c|}{ ANTEMORTEM DİŞ KAYBI } & \multirow{2}{*}{ Toplam } \\
\hline & & & Yok & Var & \\
\hline & \multirow{2}{*}{ Erkek } & $\mathrm{n}$ & 196 & 14 & 210 \\
\hline & & $\%$ & 93,3 & 6,7 & 100,0 \\
\hline & \multirow{2}{*}{ Kadın } & $\mathrm{n}$ & 301 & 29 & 330 \\
\hline & & $\%$ & 91,2 & 8,8 & 100,0 \\
\hline \multirow{2}{*}{ TOPLAM } & $\mathbf{n}$ & & 497 & 43 & 540 \\
\hline & Cinsiyet & & 92,0 & 8,0 & 100,0 \\
\hline
\end{tabular}

Tablo 19. Akgüney toplumunda yaş gruplarına göre antemortem diş kaybı dağılımı (Kadın+Erkek)

\begin{tabular}{ccccc}
\hline \multirow{2}{*}{ YAŞ } & \multicolumn{3}{c}{ ANTEMORTEM DİŞ KAYBI } & \multirow{2}{*}{ Toplam } \\
& & Yok & Var & \\
\hline \multirow{2}{*}{ Genç Erişkin } & $\mathrm{n}$ & 127 & 4 & $\mathbf{1 3 1}$ \\
& $\%$ & 96,9 & 3,1 & $\mathbf{1 0 0 , 0}$ \\
Orta Erişkin & $\mathrm{n}$ & 108 & 9 & $\mathbf{1 1 7}$ \\
& $\%$ & 92,3 & 7,7 & $\mathbf{1 0 0 , 0}$ \\
İleri Erişkin & $\mathrm{n}$ & 110 & 13 & $\mathbf{1 2 3}$ \\
& $\%$ & 89,4 & 10,6 & $\mathbf{1 0 0 , 0}$ \\
Erişkin & $\mathrm{n}$ & 152 & 17 & $\mathbf{1 6 9}$ \\
& $\%$ & 89,9 & 10,1 & $\mathbf{1 0 0 , 0}$ \\
TOPLAM & $\mathbf{n}$ & $\mathbf{4 9 7}$ & $\mathbf{4 3}$ & $\mathbf{5 4 0}$ \\
& $\mathbf{0}$ & $\mathbf{9 2 , 0}$ & $\mathbf{8 , 0}$ & $\mathbf{1 0 0 , 0}$ \\
\hline
\end{tabular}


olarak tespit edilmiştir. Alveol kemik kaybı oranı alt çenede $\% 40,5$, üst çenede ise $\% 44$ 'dür. Diş gruplar1 açısından bakıldığında \%50 oranla en yüksek 1. molar olduğu görülmektedir (Tablo 23).

Alveol kemik kaybı oranı kadın bireylerde \%45,05, erkek bireylerde $\% 45,5$, izole çenelerde $\% 34,04$, çocuklarda $\% 17,3$, bebeklerde ise $\% 18,18$ olarak tespit edilmiştir. Kadın ve erkek bireyler arasında alveol kemik kaybı açısından istatiksel olarak anlamlı fark bulunmuştur $(\mathrm{p}<0,001)$. Erkek bireylerde alveol kaybı oranı \%83,5 iken, kadın bireylerde alveol kaybı oranı $\%$ 71,1 olarak tespit edilmiştir (Tablo 24). Yaş grupları açısından ise anlamlı fark bulunmuştur $(\mathrm{p}<0,001)$. İleri erişkin bireylerde alveol kemik kayb1 $\% 92,4$ ile en yüksek orana sahiptir. Orta erişkin bireyler $\% 81,8$, genç erişkin bireyler ise \%44,2 orana sahiptir (Tablo 25).

\section{Tartışma ve Sonuç}

Akgüney toplumunun diş sağlığını belirlemek amacıyla 631 diş paleopatolojik açıdan incelenmiştir. İncelemeye kırık ve parçalı dişler dahil edilmemiştir. Dişlerdeki paleopatolojik değerlendirmeler sonucunda \%9,12 oranında diş çürüğü, $\% 28,98$ oranında diş taşı, $\% 40,29$ oranında hipoplasya, \% 7,82 oranında antemortem diş kayb1, \%1,16 oraninda apse, \%41,43 oraninda alveol kemik kaybı tespit edilmiştir (Tablo 26).

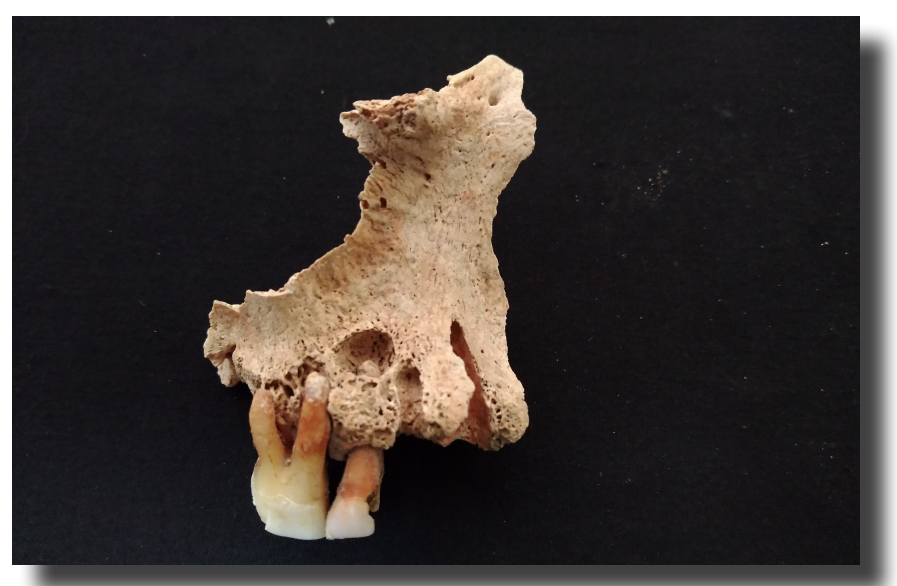

Resim 6. Apse

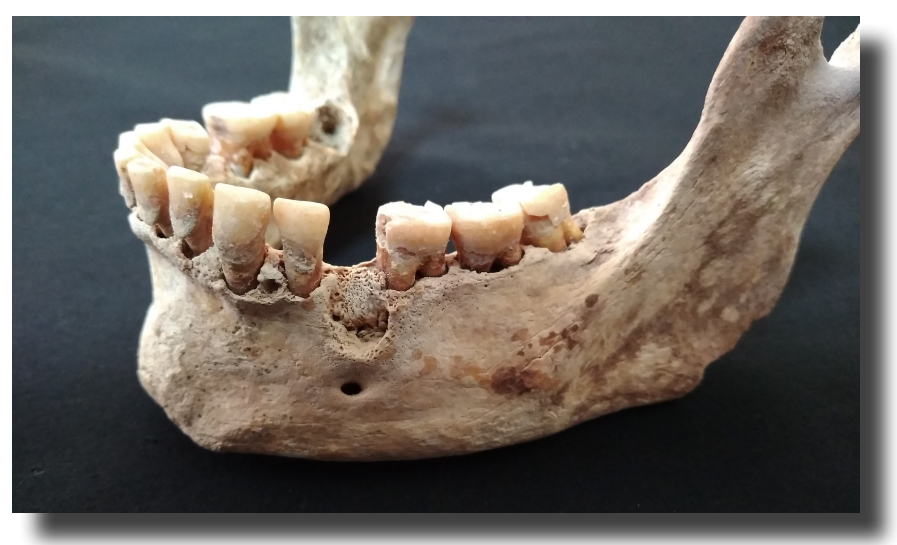

Resim 7. Alveol kemik kayb1
Çeşitli arkeolojik ve antropolojik çalışmalar, yüksek çürük sıklığg ile tarımla birlikte insan popülasyonlarındaki karbonhidrat alımının artması arasındaki ilişkiyi doğrulamıştır (Lanfranco ve Eggers, 2012). Diş çürüğü oranının neolitik devrimle birlikte artış göstermiş ve hatta sanayi devrimiyle birlikte \%80’lere ulaşmıştır. Buna nedenle araştırmacılar diş çürügünü "uygarlık hastalığı" olarak tanımlamaktadır (Uzel vd., 1987). Akgüney toplumunda diş çürüğü oranının tarım toplumlarına yakın değerde olduğu görülmektedir. Diş çürüğü sıklığ1 kadın bireylerde \%8,7 iken erkek bireylerde $\% 8,5$ 'dir. Diş çürük oranının yüksek olması toplumun karbonhidrat ağırlıklı beslenme biçimine sahip olduğunu göstermektedir. Akgüney toplumunda az ve orta dereceli aşınmaların oranı ileri derece aşınma oranlarına göre daha yüksek olduğu görülmektedir. En sık görülen aşınma derecesi ise orta dereceli aşınmadır. Aşınma derecesinin ileri derece olmaması toplumun sert besinlerle beslenmediklerini göstermektedir. Diş taşı oranı Paleolitik dönem insanlarında oldukça az oranlarda karşımıza çıkmaktadır. Tarımın başlamasıyla birlikte nişastalı ve karbonhidratlı besinlerin daha çok tüketilmesiyle birlikte diş taşı oranında da artış görülmüsstür. Akgüney Toplumunda diş taş1 oranı \%28,98 olarak tespit edilmiştir. Araştırmacılar antemortem diş kaybı nedenleri arasında ileri derece aşınma, ileri derece çürük, ileri derece diş taşı, travma ve periodontal hastalıkları göstermektedir (Özbek, 2007; Çırak vd., 2009; Özbek, 2015). Antemortem diş kaybı oranı Akgüney toplumunda \% 7,82 oranında tespit edilmiştir. Bu oran toplumun ağız sağlının çok da iyi olmadığını göstermektedir. Antik dönem toplumların sağlık yapılarının en iyi göstergelerinden biri olan hipoplasya oranı ise \%40,29 olarak tespit edilmiştir. Hipoplasyanın oluşum nedenleri arasında beslenme yetersizliği, D vitamini eksikliği, yüksek ateşli hastalıklar, travmalar olduğu göz önüne alındı̆̆ında toplumun sağlık sorunları yaşadığ1 söylenebilir. Toplumdaki apse oranı ise $\% 1,16$ 'dır.

Akgüney toplumu dişlerinden elde edilen veriler istatiksel olarak değerlendirilmiştir. Akgüney toplumu kadın ve erkek bireyleri arasında diş taşı, aşınma ve alveol kemik kaybı açısından istatiksel olarak anlamlı fark bulunmuştur. Diş taşı oranı ve aşınma oranı erkek bireylerde daha yüksek olduğu görülmüştür. Hipoplasya, antemortem diş kaybı ve diş çürügü açısından ise kadın ve erkek bireylerde istatistiksel olarak anlamlı bir fark bulunamamıştır (Tablo 27).

Kadın ve erkek bireylerde yaş grupları açısından bakıldığında ise diş çürüğü, aşınma ve alveol kemik kaybı açısından anlamlı fark bulunmuştur (Tablo 28). 

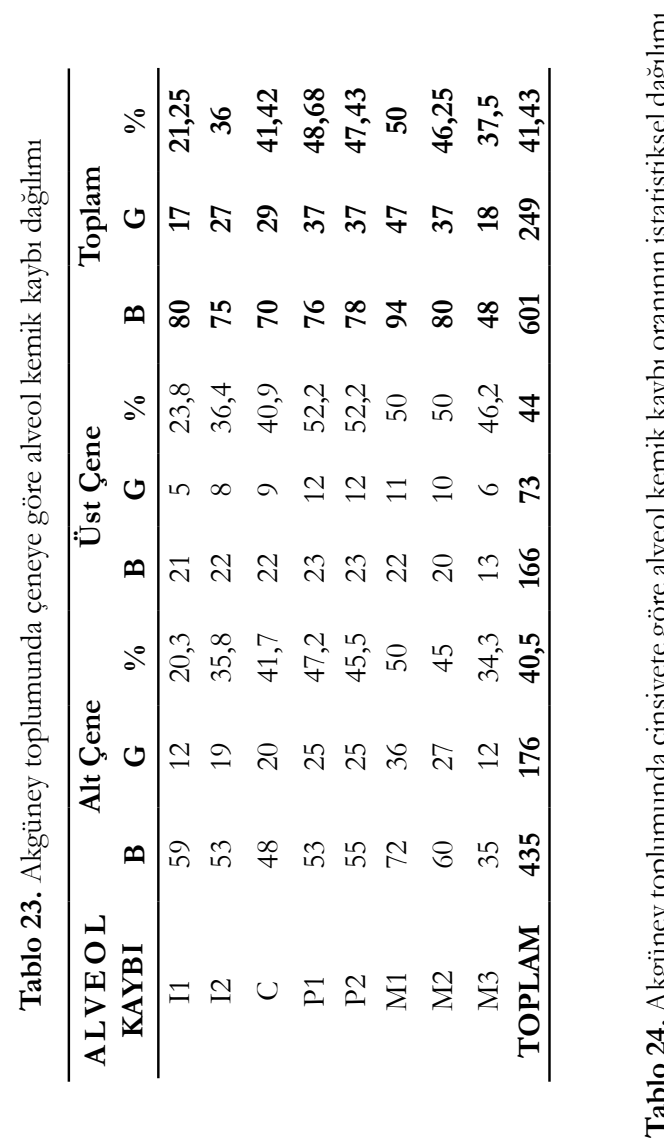

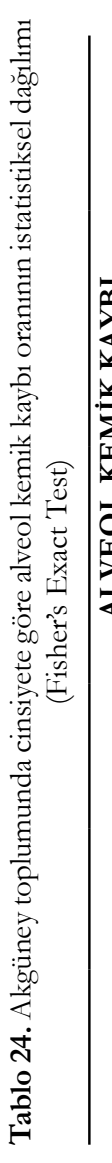

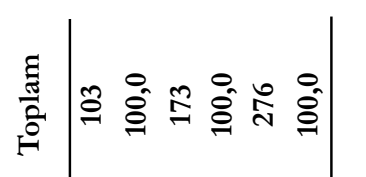

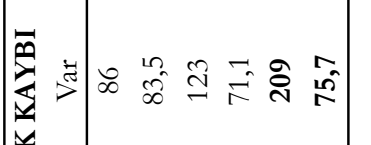

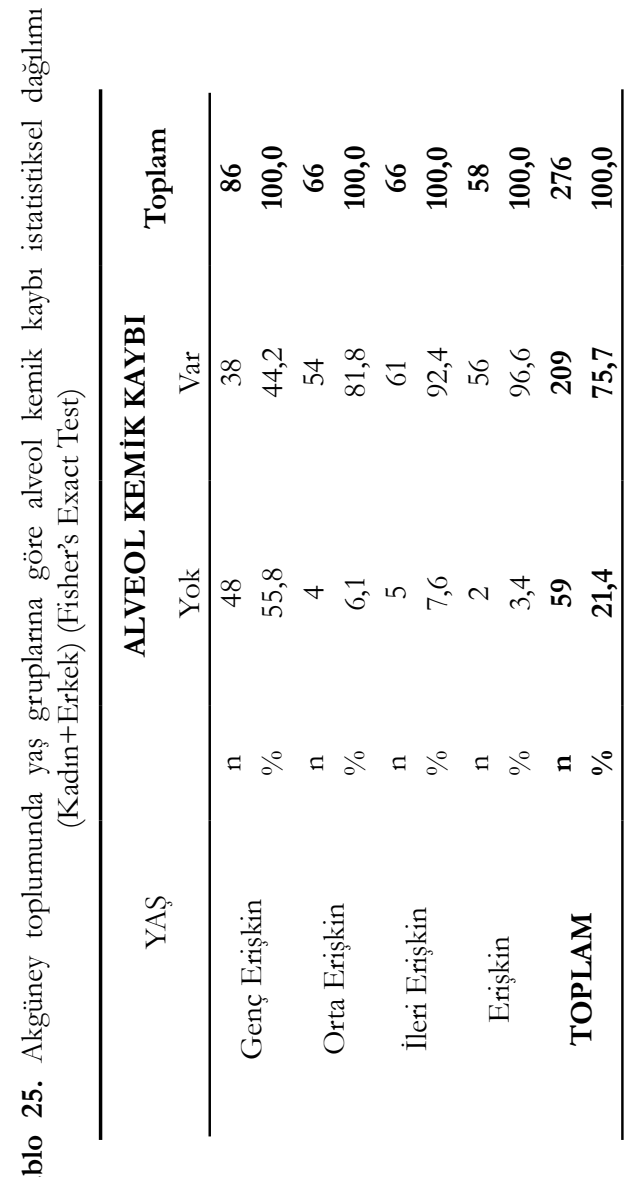

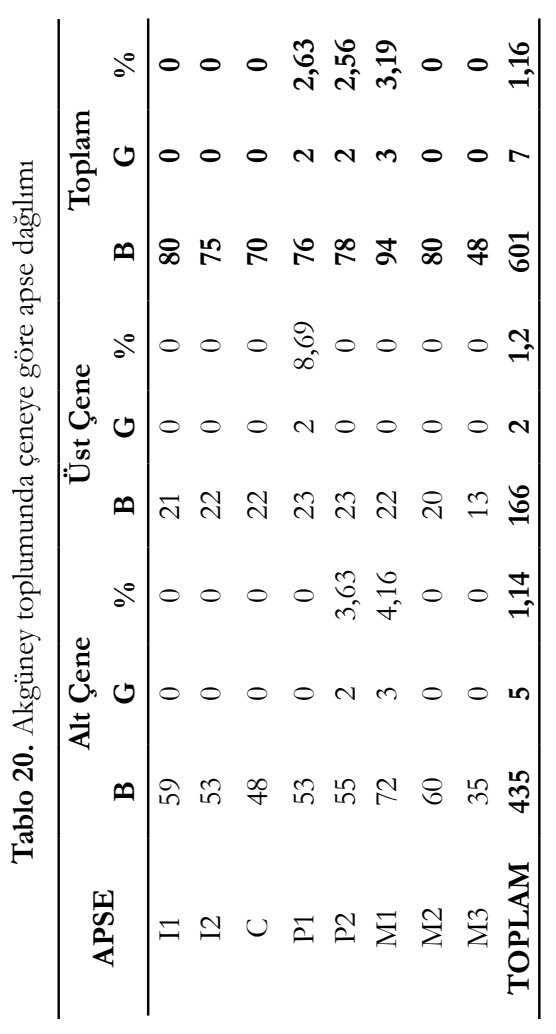

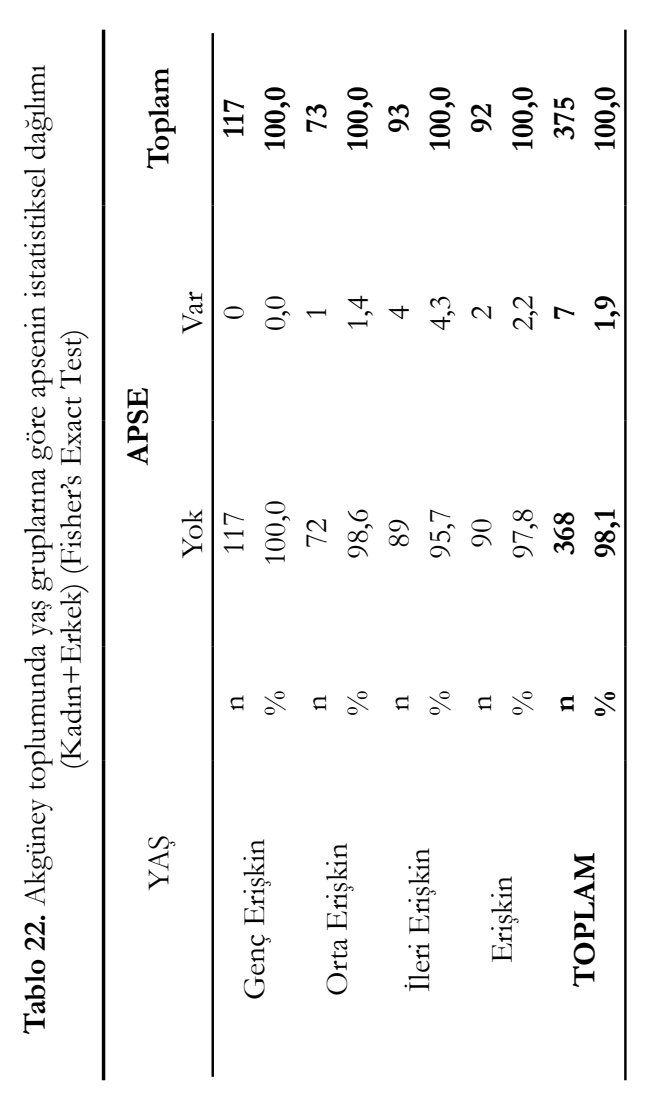


Diş çürügü, aşınma ve diş taşı ileri erişkin bireylerde daha yüksek orandadır. Diş çürüğü, aşınma ve diş taşı görülme oranlarının yaşla doğru orantılı olduğu araştırmacılar tarafindan bildirilmiştir (Çırak vd., 2009; Yilmaz Usta, 2013). Akgüney toplumunda da benzer durum görülmektedir.

Akgüney toplumu dişlerinden elde edilen paleopatolojik değerler çağdaşı olan diğer Eski Anadolu toplumlarıyla karşılaştırılmıştır (Tablo 29). Akgüney Toplumunun diş patolojileri Arslantepe (Uzel vd., 1987), Panaztepe (Güleç vd., 1998), Smyra Agorası (Bizans) (Gözlük vd., 2006), Smyrna Agorası (Helenistik/Roma) (Yaşar, 2007), Kyzikos (Gözlük vd., 2008), Milas/ Gümüşlük (Sağır vd.,2009), Alanya Kalesi (Üstündağ ve Demirel, 2009), Datça-Burgaz (Karaöz Arıhan vd., 2009), Parion (Yavuz vd., 2012), İasos (Y1lmaz Usta, 2013), Çiçekdağ (Alkan vd., 2014), Zeytinliada (Bıçak ve Suata Alpaslan, 2015), Dara Antik Kenti (Şarbak, 2017),Laodikeia (Göksal, 2017), Domaniç (Erkman vd., 2017), Kirazlıdere (Suata Alpaslan ve Uz, 2017), Amasya
(Akbacak ve Gözlük Kırmızıŏlu, 2018), Mardin/ Midyat (Acar, 2018), toplumlarıyla karşılaştırılmıştır. Akgüney toplumunun çürük oranının Arslantepe, Milas/ Panaztepe, Milas/Gümüşlük, toplumlarıyla benzer olduğu görülmektedir. Akgüney Toplumu Dara Antik Kenti ve Alanya Kalesi, Datça-Burgaz, toplumlarından düşük değerlerde olduğu görülürken, Smyrna Agorası, Laodikeia, Çiçekdağı, İasos, Amasya, Mardin/Midyat toplumlarından daha yüksek olduğu görülmektedir.

Toplumların çürük oranlarıyla beslenme biçimleri arasındaki ilişkiye bakıldığında balıkçılık ve hayvancılı̆̆ın yoğun olduğu toplumlarda çürük oranlarının daha düşük olduğu görülürken, tarımın yoğun olduğu toplumlarda ise diş çürük oranının daha yüksek olduğu görülmektedir. Diş taşı oranlarına bakıldığında da benzer şekilde tarımın yoğun olduğu bölgelerde diş taşı oranı yüksek, deniz ürünleri ve hayvancilık yapılan bölgelerde ise daha düşüktür. Akgüney toplumunun diş taşı oranı Laodikeia, Alanya Kalesi toplumlarıyla yakın değerlerdedir. Datça/ Burgaz, Amasya, Kyzikos, Çiçekdağı, toplumlarından
Tablo 26. Akgüney toplumunda diş patolojileri dağılımı

\begin{tabular}{cccc}
\hline PATOLOJİ & B & G & $\mathbf{0}$ \\
\hline Diş Çürüğ̈ & 625 & 57 & 9,12 \\
Diş Taşı & 583 & 169 & 28,98 \\
Hipoplasya & 469 & 189 & 40,29 \\
$\begin{array}{c}\text { Antemortem Diş } \\
\text { Kaybı }\end{array}$ & 690 & 54 & 7,82 \\
Apse & 601 & 7 & 1,16 \\
$\begin{array}{c}\text { Alveol Kemik } \\
\text { Kaybı Oranı }\end{array}$ & 601 & 249 & 41,43 \\
\hline
\end{tabular}

Tablo 27. Diş patolojilerinin cinsiyete göre istatistiksel değerlendirmesi

\begin{tabular}{cccc}
\hline PATOLOJi் & Kadın & Erkek & p \\
\hline Diş Çürüğü & $8,7 \%$ & $8,5 \%$ & $=0.951$ \\
Aşınma & $93,7 \%$ & $70,6 \%$ & $<\mathbf{0 . 0 0 1}$ \\
Diş Taşı & $29,4 \%$ & $52,4 \%$ & $<\mathbf{0 . 0 0 1}$ \\
Hipoplasya & $36,7 \%$ & $33,0 \%$ & $=0.552$ \\
Antemortem Diş & $8,8 \%$ & 6,7 & $=0.375$ \\
$\quad$ Kaybı & $1,2 \%$ & $3,1 \%$ & $=0.242$ \\
Apse & $71,1 \%$ & $83,5 \%$ & $<\mathbf{0 . 0 0 1}$ \\
Alveol Kemik Kayb1 \\
Oranı
\end{tabular}

Tablo 28. Diş patolojilerinin yaş gruplarına göre istatistiksel değerlendirmesi

\begin{tabular}{cccccc}
\hline PATOLOJI & $\begin{array}{c}\text { Genç } \\
\text { Erişkin }\end{array}$ & $\begin{array}{c}\text { Orta } \\
\text { Erişkin }\end{array}$ & $\begin{array}{c}\text { İleri } \\
\text { Erişkin }\end{array}$ & Erişkin & p \\
\hline Diş Çürüğü & $5,9 \%$ & $4,1 \%$ & $15,9 \%$ & $8,8 \%$ & $=0.031$ \\
Aşınma & $41,5 \%$ & $94,5 \%$ & $100,0 \%$ & $94,3 \%$ & $<\mathbf{0 . 0 0 1}$ \\
Diş Taş1 & $21,4 \%$ & $41,1 \%$ & $58,6 \%$ & $31,4 \%$ & $<\mathbf{0 . 0 0 1}$ \\
Hipoplasya & $35,1 \%$ & $29,0 \%$ & $26,8 \%$ & $45,7 \%$ & $=0.128$ \\
$\begin{array}{c}\text { Antemortem Diş } \\
\text { Kayb1 }\end{array}$ & $3,1 \%$ & $7,7 \%$ & $10,6 \%$ & $10,1 \%$ & $=0.091$ \\
$\begin{array}{c}\text { Apse } \\
\text { Alveol Kemik Kayb1 } \\
\text { Oranı }\end{array}$ & $0,0 \%$ & $1,4 \%$ & $4,3 \%$ & $2,2 \%$ & $=0.104$ \\
\hline
\end{tabular}


Şarbak | Antropoloji 38 (2019), 5-19

Tablo 29. Eski Anadolu Toplumlarında Diş Patolojileri

\begin{tabular}{|c|c|c|c|c|c|c|c|c|c|}
\hline TOPLUM & Dönem & Araştırmacı & 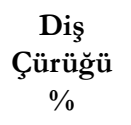 & $\underset{\%}{\text { Apse }}$ & $\begin{array}{c}\text { Diş Taş1 } \\
\%\end{array}$ & $\begin{array}{c}\text { Alveol } \\
\text { Kayb1 } \\
\%\end{array}$ & $\begin{array}{c}\text { Antemortem } \\
\text { Diş Kayb1 } \\
\%\end{array}$ & $\begin{array}{c}\text { Hipoplasya } \\
\%\end{array}$ & $\begin{array}{r}\text { Aşınma } \\
\text { (Derece) }\end{array}$ \\
\hline Milas/Gümüşlük & $\begin{array}{l}\text { Klasik, } \\
\text { Helenistik }\end{array}$ & Sağır vd.,2009 & 10,42 & 13,57 & 65 & - & 20 & 41,25 & - \\
\hline Datça/Burgaz & Helenistik & $\begin{array}{c}\text { Karaöz } \\
\text { Arrhan vd., } \\
2009\end{array}$ & 20 & 11,11 & 4,16 & 25 & 33,82 & 0 & $3 \& 4$ \\
\hline Parion & $\begin{array}{l}\text { Helenistik, } \\
\text { Roma }\end{array}$ & $\begin{array}{l}\text { Yavuz vd., } \\
2012\end{array}$ & - & 5,06 & - & 31,25 & 5,4 & - & $4+$ \\
\hline Smyrna Agoras1 & $\begin{array}{l}\text { Helenistik, } \\
\text { Roma }\end{array}$ & $\begin{array}{l}\text { Yaşar vd., } \\
2007\end{array}$ & 4,46 & 1,63 & 16,96 & 33,3 & 7,61 & 11,7 & - \\
\hline Laodikeia & Roma & Göksal, 2017 & 2,62 & 3,8 & 31,23 & 50,61 & 7,78 & 11,36 & $4 \& 3$ \\
\hline Panaztepe & Roma & $\begin{array}{l}\text { Güleç vd., } \\
1998\end{array}$ & 11,11 & - & 14,76 & - & 11,11 & 22,73 & - \\
\hline Mardin/Midyat & Roma & Acar, 2018 & 6,19 & 9,29 & - & - & 42,95 & - & - \\
\hline Amasya & Roma & $\begin{array}{c}\text { Akbacak } \\
\text { ve Gözlük } \\
\text { Kırmızıŏlu, } \\
2018\end{array}$ & 4,65 & 1,35 & 2,91 & 36,3 & 6,28 & 4,65 & 3 \\
\hline Domaniç & Roma & $\begin{array}{l}\text { Erkman vd., } \\
2017\end{array}$ & 19,57 & 2,78 & 35,38 & 67,33 & 13,39 & 17,19 & $4+\& 5$ \\
\hline Arslantepe & Geç Roma & Uzel vd., 1987 & 9,52 & - & 80 & - & 14,02 & - & - \\
\hline Dara & Geç Roma & Şarbak, 2017 & 13,63 & 3,71 & 68,32 & 69,36 & 7,15 & 34,48 & 3 \\
\hline Kyzikos & M.S.II.yy & $\begin{array}{l}\text { Gözlük vd., } \\
2008\end{array}$ & 7,76 & 0 & 5,31 & 100 & 3,79 & 56,73 & 2 \\
\hline Akgüney & $\begin{array}{l}\text { Geç Roma- } \\
\text { Erken Bizans }\end{array}$ & Bu Çalışma & 9,12 & 1,16 & 28,98 & 41,43 & 7,82 & 40,29 & 3 \\
\hline Kirazlidere & Erken Bizans & $\begin{array}{c}\text { Suata } \\
\text { Alpaslan ve } \\
\text { Uz, } 2017\end{array}$ & 7,8 & 9,21 & 67,37 & 56,81 & 35,23 & 38,29 & 4 \\
\hline Çiçekdağ1 & Erken Bizans & $\begin{array}{l}\text { Alkan vd., } \\
2014\end{array}$ & 5,66 & 0 & 1,88 & 33 & 9,09 & 22,64 & 4 \\
\hline Smyrna Agoras1 & Bizans & $\begin{array}{l}\text { Gözlük vd., } \\
2006\end{array}$ & 4,68 & 1,63 & 16,96 & 33,33 & 7,61 & 11,7 & 4 \\
\hline Alanya Kalesi & Bizans & $\begin{array}{c}\text { Üstündağ ve } \\
\text { Demirel, } 2009\end{array}$ & 12,06 & 2,3 & 29,6 & 35,3 & 2,8 & 39,07 & \\
\hline İasos & Bizans & $\begin{array}{c}\text { Yilmaz Usta, } \\
2013\end{array}$ & 5,38 & 2,1 & 50,8 & 85 & 13,87 & 15,43 & 3 \\
\hline Zeytinli Ada & $\begin{array}{l}\text { Helenistik- } \\
\text { Roma-Bizans- } \\
\text { Osmanlı }\end{array}$ & $\begin{array}{c}\text { Biçak ve Suata } \\
\text { Alpaslan, } \\
2015\end{array}$ & 4,9 & 6,61 & 71,07 & 58,42 & 38,27 & 42,64 & 4 \\
\hline
\end{tabular}

daha yüksek değerde olduğu görülmektedir. Akgüney toplumu hipoplasya oranı Kirazlıdere, Alanya Kalesi, Zeytinliada ve Milas/Gümüşlük toplumlarıyla benzer olduğu görülürken, Smyra Agoras1, Laodekia, Panaztepe, Amasya, Domaniç, İasos toplumlarından yüksek olduğu tespit edilmiştir. Apse oran1 ise Milas/Gümüşlük, Datça/Burgaz,Parion, Mardin/Midyat,Kirazlidere ve Zeytinliada toplumlarından daha düşük değere sahipken, çağdaşı olan diğer eski Anadolu toplumlarına yakın değerlerde olduğu görülmüştür. Beslenme yapısıyla yakından ilişkili olan aşınma derecelerine bakıldığında ise aşınma derecesi az/orta dereceli olan Kyzikos, Amasya, Dara toplumlarıly benzerlik göstermektedir.

Sonuç olarak bakıldığında Akgüney Toplumu diş çürüğunün yüksek oranda olduğu görülmektedir. Diş çürüğünün yüksek oranda olması toplumun karbonhidrat 
ağırlıklı beslenmiş olabileceğini göstermektedir. Ayrıca toplumda ileri erişkin bireylerde diş çürügü daha yüksek oranda olduğu tespit edilmiş ve istatiksel olarak da desteklenmiştir. Diş çürügünün daha çok arka dişleri etkilediği bilinmektedir. Akgüney Toplumu'nda da bu durum geçerliliğini korumuştur. Diş taşı birikiminin nişasta ve karbonhidrat ağırlıklı besinlerle beslenen toplumlarda daha yüksek olduğu bilinmektedir. Akgüney Toplumu'nda diş taşının da diş çürüğü gibi yüksek oranda olması toplumun karbonhidrat ağırlıklı beslenmiş olabileceğini desteklemektedir. Diş taşı birikimi yaş grupları açısından değerlendirildiğinde ileri erişkin bireylerde daha yüksek oranlarda olduğu görülmektedir. Diş taşı oranı yaş grupları açısından istatiksel olarak değerlendirildiğinde anlamlı bir farklılık tespit edilmiştir. Toplumdaki alveol kaybı oranı ve aşınmanın da yine aynı şekilde yaş grupları açısından anlamlı farklılık gösterdiği bulunmuştur. Toplumdaki antemortem diş kaybı oranının da yüksek olduğu görülmektedir. Antemortem diş kaybının nedenleri arasında ileri derece çürük, ileri derece diş taşı ve ileri derece aşınma sayılmaktadır. Akgüney Toplumu'nda antemortem diş kaybının nedenleri arasında diş çürüğü ve diş taşının etkili olabileceği düşünülmektedir. Toplumdaki apse oranı ise düşüktür. Aşınmanın orta derece olması toplumun çok fazla sert tanecikli besinlerle beslenmediklerini göstermektedir. Oluşum nedeni genellikle ateşli hastalıklar, beslenme yetersizliği, vitamin yetersizliği gibi nedenlere bağlanan hipoplasya oranın yüksek oranda olması toplumun sağlık koşullarının yetersiz olduğunu düşündürmektedir. Akgüney toplumunun diş patolojileri çağdaş topluluklarla karşılaştırıldığında da toplumun daha çok tarım toplumlarına benzer bir yap1 gösterdiği görülmektedir.

\section{Kaynakça}

Acar, A. (2018). Mardin Midyat Aktaş Mevkii İnsan İskeletlerinde Diş ve Çene Patolojileri, Mukaddime, 9(1), 151-172. DOI: $10.19059 /$ mukaddime.353493

Akbacak, H., ve Gözlük Kırmızıŏlu, P. (2018). Amasya Roma Dönemi İnsanlar1, Hitit Üniversitesi Sosyal Bilimler Enstitüsü Dergisi, ANARS AN Sempozyumu Özеl Sayns, Ekim 2018, 11(2), 1631-1650. DOI: $10.17218 /$ hititsosbil.460421

Alkan, Y., Erkman, A. C., ve Kaplan, İ. (2014). Çiçekdağ1 İskeletlerinin Paleoantropolojik Analizi, 29. Arkeometri Sonuclar Toplantısı, 77-82.

Bıçak, S., ve Suata Alpaslan, F. (2015). Zeytinli Ada İskelet Topluluğunun Diş ve Çene Patolojisi Açısından İncelenmesi, Cumburiyet Üniversitesi Fen Fakültesi Fen Bilimleri Dergisi, 36(5), 32-46. DOI: $\underline{10.17776 / \text { csj. } 79627}$

Brothwell, D. R. (1981). Digging Up Bones, London: Oxford University Press British Museum (Natural History).

Buikstra, J. E., ve Ubelaker, D. H. (1994). Standards for Data Collection from Human Skeletal Remains, Arkansas Archeological Survey Research Series, No: 44.

Caselitz, P. (1998). Caries - Ancient Plaque of Humankind, K. W. Alt, F. W. Rösing, M. Tescler-Nicola (Ed.) içinde, Dental Antropology (s. 203-226), Wien: Springer-Verlag: Wien. DOI: 10.1007/978-3-7091-7496-8_12

Comba, A., Demir, E., ve Barış Eren, N. (2019). Nutritional status and related factors of schoolchildren in Çorum, Turkey, Public Health Nutrition, 22(1), 122-131. DOI: $10.1017 /$ $\underline{\text { S1368980018002938 }}$

Çırak, M. T. (2017). Akgüney Geç Roma-Bizans Dönemi Toplumu Üzerine Paleodemografik Çalışma, Hitit Üniversitesi Sosyal Bilimler Enstitüsü Dergisi, 10(1), 249-263. DOI: 10.17218/ hititsosbil.313652

Çırak, A., Karaöz Arıhan, S., Şimşek, N., ve Erkman, A. C. (2009). Eski Anadolu toplumlarında Yaşa Bağlı Diş Kayıpları, Yaşlı Sorunlarn Arastirma Dergisi/Elderly Issues Research Journal, 2(2), 105-111.

Demir, E. (2018). Antropoloji Alanındaki Yayınların Bibliyometrik Analizi, Hitit Üniversitesi Sosyal Bilimler Enstitüsü Dergisi, ANARSAN Sempozyumu Özel Sayısı, Ekim 2018, 11(2), 15121527. DOI: $10.17218 /$ hititsosbil. 458588

Erkman, A. C., İlbey, S., ve Gökkurt, T. (2017). Domaniç Anıtsal Tonozlu Mezar İskeletlerinin Ağız ve Diş Sağlı̆̆1 ile Mine Hipoplazilerinin İncelenmesi, Kütabya Müzesi 2016 Yullı̆ğ, IV (s. 407-426). Ankara: Bilgin Kültür Sanat Yayınc1lı, Ankara.

Gözlük Kırmızıŏlu, P., Durgunlu, Ö., Özdemir, S., Taşlıalan, M., ve Sevim, A. (2006). Symrna Agoras1 İskeletlerinin Paleoantropolojik Analizi, 21. Arkeometri Sonuclar Toplantısı, Ankara.

Gözlük Kırmızıoğlu, P., Yaşar, F., Yiğit, A., ve Sevim Erol, A. (2008). Kyzikos İskeletlerinin Dental Analizi, 24. Arkeometri Sonuçlar Toplantısı, Ankara.

Göksal, N. (2017). Laodikeia İnsanlarının Ağız ve Diş Sağlığı, Social Sciences Studies Journal, 3(6), 829-842.

Güleç, E., ve Duyar, İ. (1998). Panaztepe MÖ İkinci Bin ve Roma Dönemi İskeletlerinin Antropolojik Analizi (1985-1990), Antropoloji, 13, 179-206. DOI: $10.1501 /$ antro 0000000260

Karaöz Arıhan, S., Çırak, A., ve Erkman, A. C. (2009). Datça/ Burgaz İskeletlerinin Paleoantropolojik Analizi, 25. Arkeometri Sonuçlar Toplantısı, 297-310.

Lanfranco L. P., ve Eggers, S. (2010). The usefulness of caries frequency, depth, and location in determining cariogenicity and past subsistence: A test on early and later agriculturalists from the Peruvian coast, American Journal of Physical Anthropology, 143(1), 75-91. DOI: $10.1002 /$ aipa.21296

Larsen, C. S., Shavit, R., ve Griffin, M. C. (1991). Dental Caries Evidence for Dietary Change: An Archaeological Context, M. Kelley, ve C. S. Larsen (Ed.) içinde, Advances in Dental Anthropology (s. 179-202). Wiley-Liss.

Mays, S. (1998). The Archaeology of Human Bones, London: Routledge.

Özbek, M. (2007) Dişlerle Zamanda Yolculuk, Ankara: Hacettepe Üniversitesi Yayınları.

Özbek, M. (2015). Dişlerle Tariböncesine Yolculuk, Ankara: Bilgin Kültür Sanat Yayınları. 
Roberts, C., ve Manchester, K. (2012). The Archaelogy of Disease, Third Edition. UK: The History Press.

Sağır, M., Satar, Z., Özer, İ., ve Güleç, E. (2009). Gümüşlük-Milas İskeletlerinin Ağız ve Diş Sağllğ̆1, 25. Arkeometri Sonuclar Toplantısı, Ankara.

Schultz, M., Carli-Thiele, P., Schmidt-Schultz, T. H., Kierdorf, U., Kierdorf, H., Teegen, W. R., ve Kreutz, K., (1998). Enamel Hypoplasias in Archaeological Skeletal Remains, K. W. Alt, F. W. Rösing, ve M. Teschler-Nicola, M. (Ed.) içinde, Dental Anthropology: Fundamentals, Limits, and Prospects (s. 293-312), Wien: Springer-Verlag. DOI: 10.1007/978-3-7091-7496-8 16

Suata Alpaslan, F., ve Uz, B. (2017). Kirazlidere İskelet Topluluğunun Çene ve Diş Patolojisi Açısından İncelenmesi, CÜ Sosyal Bilimler Dergisi, 41(2), 1-19.

Şarbak, A. (2017). Dara Geç Roma Dönemi Antik Kenti Toplumunun Ağız ve Diş Sağlığ1 Üzerine Bir Araştırma, Eurasian Academy of Sciences Eurasian Art \& Humanities Journal, 7, 10-35.

Şarbak, A. (2017). Dara Antik Kenti Toplumunda Diş Çürügü ve Anadolu Toplumlarıyla Karşılaştırılmas1, Avrasya Sosyal ve Ekonomi Arastırmalar Dergisi (ASEAD), 4(11), 197-214.

Ubelaker, D. H. (1978). Human Skeletal Remains, Chicago: Smithsonian Institution, Adline Publishering Company.

Uzel, İ., Alpagut., B., ve Kofoğlu, S. (1988). Arslantepe (Malatya) Geç Roma Dönemi İskeletlerinde Diş Çürüğü, Aşınmalar ve Periodonta1 Hastalıklar, III. Arkeometri Sonuclan Toplantısı, 31 53, Ankara.

Üstündağ, H., ve Demirel, A. (2009). Alanya Kalesi İskelet Topluluğunda Ağız ve Diş Sağllğı, Hacettepe Üniversitesi Edebiyat Fakültesi Dergisi, 26(1), 219-234.

Vanna, V. (2007). Sex and Gender Related Health Status Differences in Ancient and Contemporary Skeletal Populations, Papers from the Institute of Archaeology, 18, 114-147. DOI: 10.5334/pia.306

White, T. D., Black, M. T., ve Folkens, P. (2012). Human Osteology, Third Edition, USA: Academic Press.

Yaşar, Z., Yiğit, A., Gözlük Kırmızıŏ̆lu, P., ve Sevim Erol, A. (2007). Smyrna Agorası İnsanlarının Ağız ve Diş Sağlığı, 23. Arkeometri Sonuclar Toplantısi, 127-140.

Yavuz, A. Y., Özdemir, S., Ürker, K., ve Sevim Erol, A. (2012). Parion İskeletlerinin Antropolojik Analizi, 28. Arkeometri Sonuclar Toplantısi, 69-82, Ankara.

Yilmaz Usta, N. D. (2013). Iasos (Bizans Donemi) Toplumunda Ağ̣ı ve Diş Sağlı̆̆1, Antropoloji, 25, 117-154. DOI: $10.1501 /$ antro 0000000032 